\title{
Response of cotton to temperature, rainfall and sunshine hours at Kovilpatti, Tamil Nadu, India
}

\author{
S. Subbulakshmi \\ Agricultural Research Station (T.N.A.U.), Kovilpatti (T.N.) India \\ (Email: sumiagri@rediffmail.com)
}

\begin{abstract}
Three date of sowing with four levels of spacing were tried to know growing degree days (GDD), heliothermal units (HTU) photo thermal units (PTU) requirement of crop and heat use efficiency (HUE) for prediction of phenophases, growth and yield of cotton. Field experiments was conducted during 2010-11 in Rabi season (October - December) at Agricultural Research station, Kovilpatti (Latitude 9.17'N, Longitude 77.88'E and elevation (AMSL) 90 m), Tamil Nadu, India, using cotton (NCS 145). The treatment combinations comprised of three dates of sowing viz., $\mathrm{D}_{1}-39^{\text {th }}, \mathrm{D}_{2}-41^{\text {st }}$ and $\mathrm{D}_{3}-43^{\text {rd }}$ standard weeks (pre monsoon, monsoon and post monsoon sowing, respectively) in main plot with four different spacing of $S_{1}-90 \times 60, S_{2}-90 \times 45, S_{3}-75 \times 60, S_{4}-$ $75 \mathrm{x} 45$ in the sub plot. The highest HUE of $0.815 \mathrm{~g} \mathrm{~m}^{-2}$ per ${ }^{\circ} \mathrm{C}$ day for cotton kapas yield was recorded by pre monsoon sown crop and GDD directly reflected in cotton kapas yield. The maximum and minimum temperature, sun shine hours and rainfall had positive correlation with yield of the crops. Higher cotton kapas yield was recorded by pre monsoon sown crop due to favourable weather factors.
\end{abstract}

Key Words : Cotton, Temperature, Rainfall, GDD, HTU, HUE

View Point Article : Subbulakshmi, S. (2019). Response of cotton to temperature, rainfall and sunshine hours at Kovilpatti, Tamil Nadu, India. Internat. J. agric. Sci., 15 (1) : 120-123, DOI:10.15740/HAS/IJAS/15.1/120-123. Copyright@ 2019: Hind Agri-Horticultural Society. Article History : Received : 15.10.2018; Revised : 05.12.2018; Accepted : 11.12.2018 